\title{
Developing Extracellular Matrix Technology to Treat Retinal or Optic Nerve Injury
}

\author{
(1)Tanchen Ren, ${ }^{1,2}$ Yolandi van der Merwe, ${ }^{1,2,3}$ and Michael B. Steketee ${ }^{1,2,4}$
}

DOI:http://dx.doi.org/10.1523/ENEURO.0077-15.2015

\begin{abstract}
${ }^{1}$ Department of Ophthalmology, School of Medicine, University of Pittsburgh, Pittsburgh, Pennsylvania 15216,
${ }^{2}$ McGowan Institute for Regenerative Medicine, University of Pittsburgh, Pittsburgh, Pennsylvania $15219,{ }^{3}$ Department of Bioengineering, Swanson School of Engineering, University of Pittsburgh, Pittsburgh, Pennsylvania 15260, ${ }^{4}$ Center for Neuroscience, University of Pittsburgh, Pittsburgh, Pennsylvania 15216
\end{abstract}

\begin{abstract}
Adult mammalian CNS neurons often degenerate after injury, leading to lost neurologic functions. In the visual system, retinal or optic nerve injury often leads to retinal ganglion cell axon degeneration and irreversible vision loss. CNS axon degeneration is increasingly linked to the innate immune response to injury, which leads to tissue-destructive inflammation and scarring. Extracellular matrix (ECM) technology can reduce inflammation, while increasing functional tissue remodeling, over scarring, in various tissues and organs, including the peripheral nervous system. However, applying ECM technology to CNS injuries has been limited and virtually unstudied in the visual system. Here we discuss advances in deriving fetal CNS-specific ECMs, like fetal porcine brain, retina, and optic nerve, and fetal non-CNS-specific ECMs, like fetal urinary bladder, and the potential for using tissue-specific ECMs to treat retinal or optic nerve injuries in two platforms. The first platform is an ECM hydrogel that can be administered as a retrobulbar, periocular, or even intraocular injection. The second platform is an ECM hydrogel and polymer "biohybrid" sheet that can be readily shaped and wrapped around a nerve. Both platforms can be tuned mechanically and biochemically to deliver factors like neurotrophins, immunotherapeutics, or stem cells. Since clinical CNS therapies often use general anti-inflammatory agents, which can reduce tissue-destructive inflammation but also suppress tissue-reparative immune system functions, tissue-specific, ECM-based devices may fill an important need by providing naturally derived, biocompatible, and highly translatable platforms that can modulate the innate immune response to promote a positive functional outcome.
\end{abstract}

Key words: axon regeneration; ECM; immunotherapy; regenerative medicine; retinal ganglion cell

\section{Significance Statement}

Failed regeneration in CNS neurons is increasingly linked to the innate response of the immune system to injury, which leads to tissue destructive inflammation and scarring. Extracellular matrix (ECM) technology has been widely successful clinically in modulating the innate response of the immune system to reduce inflammation and to increase positive tissue remodeling, over scarring. ECM technology is now being developed to treat CNS injuries. Here we discuss recent advances in developing ECM technology in two platforms, an injectable ECM hydrogel and an ECM hydrogel and polymer "biohybrid" sheet. Unlike traditional immunosuppressive treatments that also suppress beneficial immune system functions, ECMbased devices offer a natural biocompatible platform for modulating the innate immune response to promote functional CNS tissue repair. 


\section{Introduction}

Approximately 2.5 million cases of ocular trauma are reported annually in the United States, with about 50,000 of these cases resulting in permanent vision loss at an estimated lifetime cost of approximately $\$ 900,000$ per person according to the National Federation of the Blind (2013). Additionally, $\sim 80$ million people in the United States experience eye-blinding diseases. Worldwide, $\sim 285$ million people are visually impaired, and this number is predicted to increase with increasing longevity (Pascolini and Mariotti, 2012). However, we lack a clinically relevant regenerative medicine approach to promoting constructive tissue remodeling in the neural tissues of the eye, the retina, and the optic nerve. This review discusses developing extracellular matrix (ECM) hydrogel technology to promote constructive tissue remodeling, over scarring, after trauma or disease by modulating the innate immune response to injury. Tissue-specific ECM hydrogels may also provide a more biologically relevant delivery platform for existing retinal and optic nerve repair technologies, like delivering neurotrophic factors, stem or progenitor cells, or antioxidants, among others. Though this review focuses primarily on the retinal ganglion cells (RGCs), microglia, and macrophages, the potential benefits of ECM technology are widely applicable to other neural and glial populations throughout the CNS.

In adult mammalian CNS neurons, failed axon regeneration remains a persistent problem due to the variety of factors prohibiting axon regeneration. In the visual system, injury to RGC axons often leads to progressive RGC axon degeneration, and ultimately to RGC death and permanent vision loss. The inability of CNS neurons to regenerate injured axons is due to multiple intrinsic and injury-induced factors that suppress axon regeneration, including poor intrinsic axon growth ability (Goldberg et al., 2002), altered organelle dynamics (Lathrop and Steketee, 2013), lost neurotrophic support, (Mansour-

Received July 12, 2015; accepted September 9, 2015; First published September 18, 2015.

The authors declare no competing financial interests.

Author contributions: T.R. and Y.v.d.M. performed research; T.R., Y.v.d.M., and M.B.S. wrote the paper; M.B.S. designed research.

This research was funded by the Department of Defense Office of Congressionally Directed Medical Research Programs and the Clinical and Rehabilitative Medicine Research Program (to M.B.S.), Grant MR130444; the Competitive Medical Research Fund, University of Pittsburgh (to M.B.S.); the Pennsylvania Lions Sight Conservation \& Eye Research Foundation (to M.B.S.); the Sterling Lions Club of Pennsylvania District 24A and Dance for Sight (to M.B.S.); Start-up funds, Department of Ophthalmology, University of Pittsburgh (to M.B.S.); National Institutes of Health CORE Grant P30-EY008098; the Eye and Ear Foundation of Pittsburgh, PA; and an Unrestricted Grant from Research to Prevent Blindness, New York, NY

Acknowledgments: We thank Anne Faust and Asma Naqvi for careful proofreading and editing.

Correspondence should be addressed to Michael B. Steketee, Department of Ophthalmology, Center for Neuroscience, McGowan Institute for Regenerative Medicine, University of Pittsburgh, 450 Technology Drive, Suite 300, Pittsburgh, PA 15213. E-mail: SteketeeM@UPMC.edu.

DOI:http://dx.doi.org/10.1523/ENEURO.0077-15.2015

Copyright (C) 2015 Ren et al.

This is an open-access article distributed under the terms of the Creative Commons Attribution 4.0 International, which permits unrestricted use, distribution and reproduction in any medium provided that the original work is properly attributed.
Robaey et al., 1994), glial expressed inhibitory molecules like Nogo-A, myelin-associated glycoprotein, and oligodendrocyte myelin glycoprotein (McKeon et al., 1999; Tang et al., 2001), and the innate immune response (Horn et al., 2008; Fig. 1), among others.

After injury, RGCs can regenerate axons over long distances, if provided a suitable substrate like a peripheral nerve graft, to reinnervate visual centers in the rodent brain (Vidal-Sanz et al., 1987). In rodent models, transected RGC axons initially display transitory axonal sprouting, indicating that some intrinsic capacity for regeneration exists, and then $\sim 90 \%$ undergo apoptotic cell death within 14 d (Berkelaar et al., 1994). After injury, activated glia, both in the retina and in the optic nerve, produce pro-regenerative neurotrophic factors (Hauk et al., 2008), indicating that the glial population also has some capacity for supporting axon regeneration in the adult mammalian CNS. However, reactive astrocyte and other glial cell-mediated remodeling of the ECM (Fisher et al., 2005; Lewis et al., 2010; Luna et al., 2010; Kayama et al., 2011) ultimately produces a glial scar containing proteoglycans (Silver and Miller, 2004), including neurocan, brevican, phosphacan, and versican (Jones et al., 2003; Butt et al., 2004), and myelin-derived molecules that inhibit axon growth in CNS tissues (Trimmer and Wunderlich, 1990; Schwab, 2010). Thus, in developing new regenerative therapies for CNS injuries, a more comprehensive "tissue-level" approach is required that includes modulating glial cell activation and ECM remodeling to suppress scarring.

Combinatorial approaches, targeting one or more axon growth-inhibiting factors by molecular and/or genetic manipulations, can improve RGC survival and increase axon regeneration in the visual system (Kurimoto et al., 2010). In optic nerve crush studies, full-length axon regeneration was reported in mice treated with combinatorial therapies that increase intrinsic axon regeneration potential, indicating that injured RGC axons can regenerate through the "host" optic nerve to reinnervate the brain. Though the percentage of neurons that regenerated sufficiently to reinnervate the brain was low, encouragingly, some functional recovery was reported (de Lima et al., 2012). Additionally, studies using peripheral nerve grafts and bioengineered neural bridges have shown that transected RGC axons can also regenerate over long distances through nonhost tissues (Berry et al., 2008) and biomaterials (Wittmer et al., 2011). In some cases, transected RGC axons regenerated sufficiently to reinnervate the brain. However, these studies also reported that a low percentage of axons regenerated successfully (Bray et al., 1987). Instead of trying to target numerous growth-inhibiting factors, which may lead to a never-ending series of complications due to off-target effects, or relying on foreign tissue or bioengineered neural bridges, which may not be compatible in the long term and are difficult to envision routing properly to the numerous visual centers in the brain, a more logical approach may be to treat CNS injury at the tissue level by altering the default healing response to injury. 


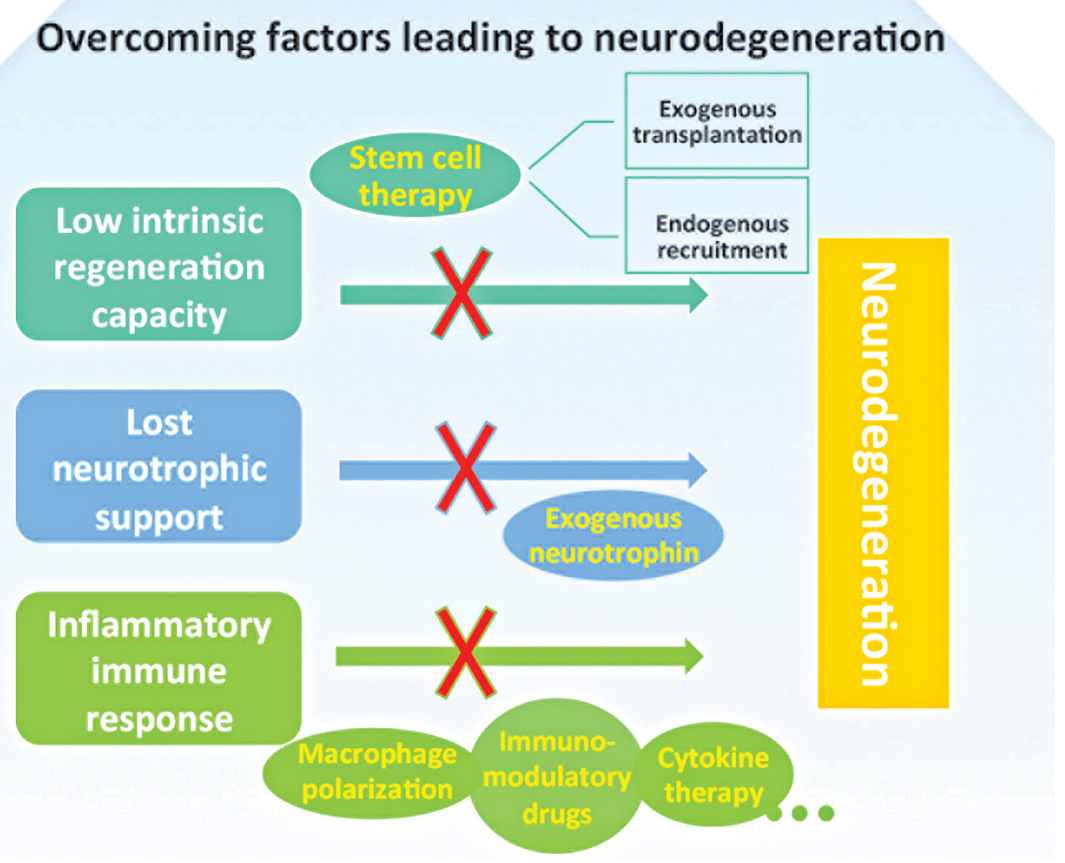

Figure 1. Numerous barriers must be overcome to prevent neural degeneration. The low intrinsic regeneration capacity of RGCs, lost neurotrophic support, and an inflammatory immune response are three major factors leading to neurodegeneration. Therapies overcoming these barriers are showing promise in preclinical and clinical models, including stem cell delivery from both exogenous and endogenous sources; neurotrophin delivery; and immunomodulatory therapies using macrophage polarization, immunomodulatory drugs, and cytokines.

\section{The innate immune response and CNS regeneration}

The default healing response in the CNS is closely linked to the timing and nature of the innate immune response to injury (Koh and DiPietro, 2011; Godwin et al., 2013). After CNS trauma, damaged and dying cells release chemokines and other molecules (Popovich and Longbrake, 2008; Brinkmann and Zychlinsky, 2012) that modulate multiple innate immune system cells, including neutrophils (Schnell et al., 1999; Donnelly and Popovich, 2008), macrophages (Soares et al., 1995), and microglia (Hains and Waxman, 2006), among others. Studies from animals that can regenerate CNS tissues, including retina, optic nerve, and brain, indicate that the temporal and spatial organization of macrophage phenotypes is a critical determinant in the overall healing response (Shechter et al., 2009, 2013). For example, in vertebrates like the axolotl, the temporal and spatial patterning of macrophage phenotypes appears to determine whether injured tissues are repaired functionally or whether scar tissue is formed (Godwin and Rosenthal, 2014).

Macrophages and microglia, the resident macrophagelike cells in the CNS, alter their phenotypes along a spectrum, ranging from the classically activated proinflammatory, M1-like phenotype to the alternatively activated anti-inflammatory, M2-like phenotype (Martinez and Gordon, 2014). This spectrum of phenotypes and their spatial and temporal ratios to one another play distinct roles in the healing process in most vertebrates, determining whether a tissue forms scar tissue or whether a tissue remodels to preserve or restore function. M1-like and M2-like macrophages can generally be distinguished by assessing cytokine, receptor, and enzyme expression levels. Classic M1-like markers include, but are not limited, to proinflammatory markers like interleukin (IL)- $1 \beta$, IL-6, IL-12, tumor necrosis factor- $\alpha$, inducible nitric oxide synthase, and C-X-C motif chemokine 10, while alternatively activated M2-like markers include transforming growth factor- $\beta$ (TGF- $\beta$ ), IL-10, IL-1 receptor antagonist, arginase-1, CD206, and CD163 (Kawamura et al., 2009; Hao et al., 2012; Martinez and Gordon, 2014). Of note, M1- and M2-like markers can vary significantly depending on species, tissue, or organ, and the nature of the injury or pathogen. Thus, careful consideration of multiple markers must be used to identify macrophage phenotypes. Generally, proinflammatory $\mathrm{M} 1$-like cells produce high levels of oxidative metabolites (e.g., nitric oxide and superoxide) and proinflammatory cytokines, which are essential for host defense and tumor cell killing (Sica and Mantovani, 2012). However, these factors also cause secondary tissue damage, expand the injury area, and contribute to increased scarring (Mantovani et al., 2004). In contrast, M2-like macrophages are generally thought to be antiinflammatory and promote functional tissue remodeling (Kigerl et al., 2009). Immunodepleting M1-like macrophages in adult mammals can reduce scarring and improve tissue preservation and functional outcomes. Conversely, cytokines like IL-4 or IL-13 promote an M2like phenotype (Mokarram et al., 2012), which is thought to reduce tissue-destructive inflammation and to increase 


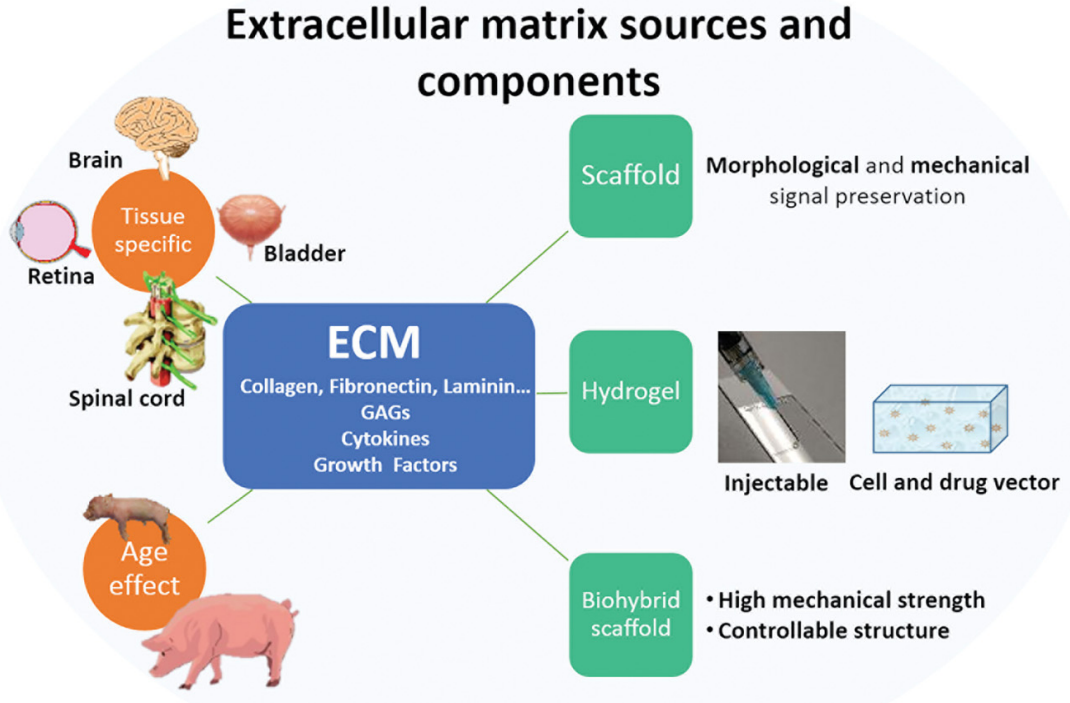

Figure 2. ECMs can be derived from different animal tissues or organs, each with a unique compliment of proteins, carbohydrates, extracellular matrix molecules, growth factors, and cytokines. The ECM is a flexible platform that can be used as a natural material bioscaffold, an injectable hydrogel, or combined with polymeric materials to form biohybrid devices with controllable mechanical and biochemical properties. Each form can be augmented with cells or other bioactive molecules to improve the healing response.

functional tissue remodeling (Sica et al., 2006). In CNS tissues, M1 macrophages are neurotoxic and possess only moderate axon growth-promoting effects (Kigerl et al., 2009), whereas M2 macrophages are non-neurotoxic and can promote long-distance axon growth, even in the presence of growth-inhibitory molecules like chondroitin sulfate proteoglycans (CSPG) or myelin (Kigerl et al., 2009). The M2 phenotype has been implicated in tissue repair through cytokine secretion that in turn supports new ECM deposition and tissue remodeling during the wound-remodeling stage (Mosser and Edwards, 2008). Thus, after CNS injury, immunomodulatory therapeutics designed to positively modulate the ratio between M1-like and M2-like macrophages are a logical approach to improving CNS repair.

\section{Extracellular matrix technology}

How can we modulate microglia and macrophage phenotypes to promote a more favorable healing outcome in CNS tissues? Extracellular matrix technology is an attractive candidate. Naturally derived ECM bioscaffolds have been shown to modulate the innate immune response in wide-ranging applications throughout the body. ECM technology uses ECM bioscaffolds derived by decellularizing various healthy mammalian tissues or organs primarily from porcine or equine sources (Gilbert et al., 2006; Badylak, 2007; Fig. 2). ECM bioscaffolds maintain many of the bioactive molecules specific to the native tissue, including collagens, glycosaminoglycans, laminins, and growth factors (Crapo et al., 2012; Turner and Badylak, 2013), that are unavailable in synthetic materials. When properly prepared, ECM does not produce an adverse immune response (Keane et al., 2012) and is highly translatable clinically. Over 4 million patients have been treated with $>60$ Food and Drug Administration-approved, ECMbased products used to treat injuries in varied tissues, including skin, heart, esophagus, bladder, muscle, bone, and peripheral nerves, among others (Badylak et al., 2005; Badylak, 2007; Valentin et al., 2010; Wolf et al., 2012). However, few initial studies have analyzed whether ECM technology can modulate the default healing response in the brain or spinal cord (Liu et al., 2011; Bible et al., 2012; Zhang et al., 2013), and applying ECM technology to retinal or to optic nerve injuries has been virtually unexplored.

ECM bioscaffolds can modulate several components of the default healing response relevant to constructive CNS tissue remodeling. For example, porcine small intestine ECM (SIS-ECM) bioscaffolds induce angiogenesis in an esophageal resection and repair model in dog (Badylak et al., 2000), and both angiogenesis and neurogenesis in a murine model of volumetric skeletal muscle loss (Sicari et al., 2012b). SIS-ECM bioscaffolds can also promote innervation in a rodent abdominal wall reconstruction model (Agrawal et al., 2009). ECM degradation products derived from digesting urinary bladder ECM can direct both progenitor cells and resident tissue-derived cells to repopulate the injury site in a mouse model of digit amputation (Agrawal et al., 2011, 2012). Decellularized peripheral nerve ECM can stimulate axon regeneration in the rodent sciatic nerve (Vasudevan et al., 2014) as well as in human clinical studies in part by stimulating Schwann cell migration and myelination (Karabekmez et al., 2009; Cho 
et al., 2012). ECM-based hydrogels can reduce glial activation in rodent CNS trauma models (Lin et al., 2009; Khaing et al., 2011) with reports of improved neurologic function (Huang et al., 2012). Finally, ECM bioscaffolds also possess antimicrobial activities (Brennan et al., 2006; Medberry et al., 2012), which are critical in any successful wound-healing scenario.

However, modulating the innate response of the immune system to injury is increasingly recognized as the critical factor necessary to bias the default healing response toward site-appropriate, functional tissue remodeling. ECM-derived factors are hypothesized to modulate the innate immune response by regulating the spatial and temporal ratios between M1-like and M2-like macrophage and microglia phenotypes. Naturally derived ECM bioscaffolds have been shown to increase M2-like, proregenerative macrophages at the ECM implantation site in muscle defect models based on both immunohistochemical and quantitative PCR for M1-like and M2-like macrophage markers (Badylak et al., 2008; Brown et al., 2009, 2012). However, whether ECM can similarly regulate M1/M2 phenotypes in infiltrating macrophage and resident microglia, which differ considerably from monocytederived macrophages (Cherry et al., 2014), in the CNS is largely unknown. Depleting or inhibiting M1 macrophage activity has long been recognized as being neuroprotective in the CNS (Giulian and Robertson, 1990; Gris et al., 2004). In a rodent traumatic brain injury (TBI) model, urinary bladder matrix (UBM) injected into the brain did not detectably activate microglia or astrocytes, while decreasing the lesion volume and increasing functional recovery (Zhang et al., 2013). In a rodent spinal cord injury model, M2-like macrophage-derived factors were shown to reduce astrocyte activation, which in turn reduced M1-like macrophage infiltration via a putative feedback mechanism (Haan et al., 2015). Since the glial scar contains inhibitory molecules like CSPGs, which not only prohibit axon regeneration (McKeon et al., 1999) but also appear to polarize macrophages toward an M1 phenotype (Bartus et al., 2014; Didangelos et al., 2014), the glial scar appears to promote proinflammatory signaling indefinitely at the lesion site (Kigerl et al., 2009). Thus, the antigliotic and immunomodulatory properties of naturally derived ECM bioscaffolds should be further explored in the CNS as a preemptive strategy for reducing scarring.

How do ECM bioscaffolds modulate the default healing response at a signaling level? ECM-induced changes in the default healing response are attributed to both chemotactic and chemotrophic factors, released during ECM degradation (Reing et al., 2009), that direct siteappropriate cellular migration and differentiation. In turn, appropriately differentiated cells feedback positively by exerting site-appropriate changes in the extracellular matrix in a process termed "dynamic reciprocity" (Bissell and Barcellos-Hoff, 1987; Berthiaume et al., 1996; Nelson and Bissell, 2006). After ECM is applied in vivo, ECM bioscaffolds are rapidly invaded and degraded by macrophages and other immune cells. During degradation, factors are released, including growth factors that contribute to healing, like VEGF (Sage, 1997; Hodde et al., 2001), TGF- $\beta$,
PDGF, BMP4, and bFGF (McDevitt et al., 2003; Badylak, 2004). Recent studies have demonstrated that biologically active ECM degradation products are released from collagen, laminin, and fibronectin molecules (Davis et al., 2000; Adair-Kirk and Senior, 2008; Brennan et al., 2008; Crisan et al., 2008; Reing et al., 2009) and from angiogenic proteins (Sage, 1997; Hodde et al., 2001). These so-called "matricryptic peptides" can recruit endogenous stem cells and direct their migration (Agrawal et al., 2011), proliferation (Reing et al., 2009), and differentiation into site-appropriate cell types. For example, peptides generated by enzymatic degradation of urinary bladder ECM identified a C-terminal telopeptide of collagen III $\alpha$ that can direct stem cell chemotaxis in vitro and attract Sox $2^{+} /$ $\mathrm{Sca} 1^{+} / \mathrm{Lin}^{-}$progenitor cells in vivo in a mouse digit amputation model (Agrawal et al., 2011). Moreover, in a dog musculoskeletal model, ECM-derived scaffolds have been shown to recruit $\mathrm{CD} 133^{+}$myogenic progenitor cells (Turner et al., 2012) as well as Sca $1^{+} / \mathrm{PW} 1^{+}$interstitial muscle stem cells (Perniconi et al., 2011). Whether similar mechanisms can direct CNS stem cell populations remains to be determined but is an ongoing area of investigation.

Both age and tissue type are important factors with ECM-derived from younger, tissue-matched sources, often achieving increased progenitor cell recruitment and enhanced ECM-mediated alteration of the default immune response toward a pro-repair M2 macrophage phenotype (Brennan et al., 2008; Sicari et al., 2012a). Thus, tissuematched ECM bioscaffolds, like porcine brain, optic nerve, or retinal ECMs, may be good candidates for modulating the innate immune response in CNS-specific, brain, spinal cord, retinal, or optic nerve injuries. Furthermore, recent advances in decellularization techniques have permitted ECM to be derived from delicate tissues previously not decellularizable using established protocols, including fetal brain, optic nerve, and retina (Fig. 3). The ability to use hydrogels derived from fetal, tissuematched sources, particularly in delicate CNS tissues like the retina, is an exciting and open area for investigation. Preliminary in vitro studies indicate fetal, tissue-specific ECMs can increase retinal ganglion cell survival and axon regeneration significantly over adult tissue-derived versions (Fig. 4).

\section{Modulating inflammation is critical to a positive outcome in CNS tissues like retina and optic nerve}

Inflammation plays a central role in the healing outcome and in the rate of disease progression. Inflammation exerts both positive and negative effects on RGC regeneration. After incisional or penetrating trauma to the retina, cells die in all retinal layers adjacent to the wound (Sipperley et al., 1978; Turner et al., 1986). Similarly, all photoreceptors adjacent to the wound die by apoptosis or programmed necrosis. Retinal cell death is accompanied by the rapid onset of glial activation (Yoshida et al., 1995; Fisher et al., 2005). Within 30 min of injury, cell cyclerelated transcription factors that regulate astrocyte proliferation, like c-Fos and Jun-B, are upregulated (Fisher 


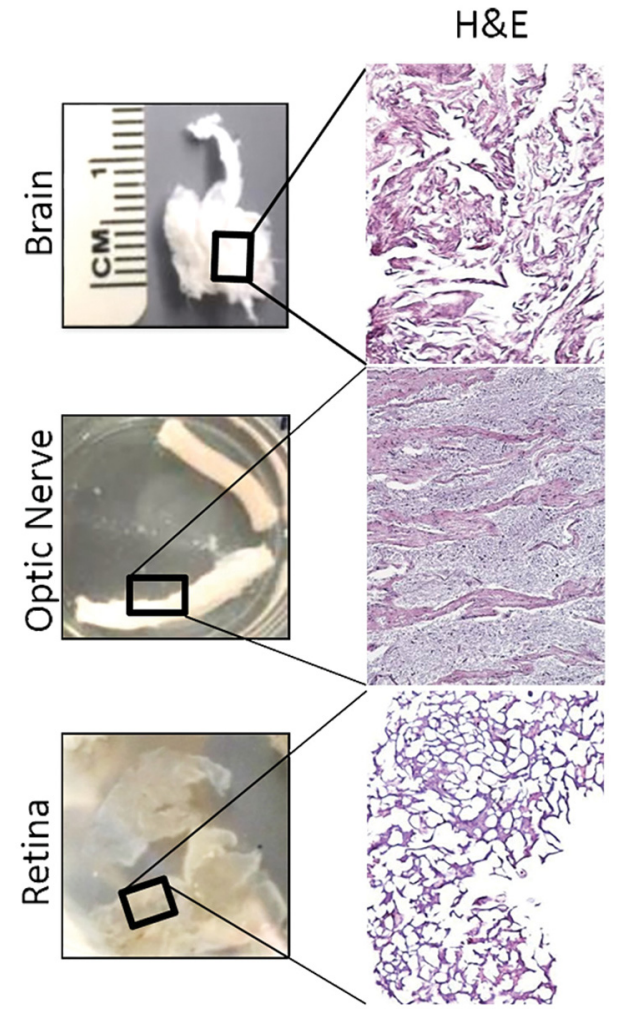

Fetal ECM can be derived from porcine sources.

Figure 3. Images and H\&E staining of different decellularized CNS ECMs derived from fetal porcine tissues.

et al., 2005). Within $3 \mathrm{~d}$, glial fibrillary acidic protein and proliferating cell nuclear antigen, markers of activated and proliferating glial cells, are upregulated (Yoshida et al., 1995; Vazquez-Chona et al., 2004). Activated glia in the retina and in the optic nerve produce multiple pro-
A

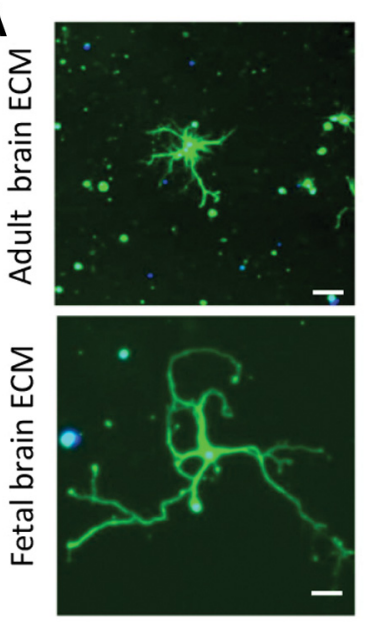

B

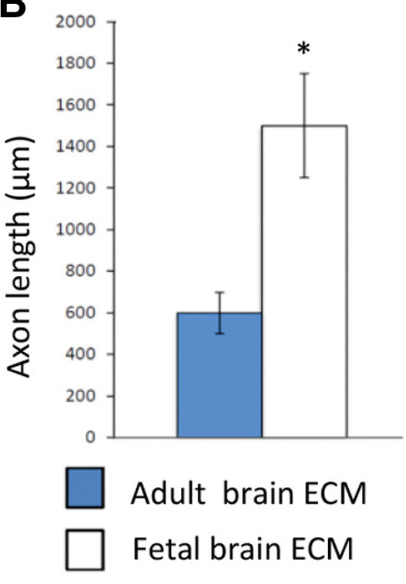

Figure 4. RGCs grow longer processes in ECM derived from younger, homologous tissue sources. $\boldsymbol{A}$, Fluorescence images of purified primary rat RGCs cultured in adult or fetal brain ECMs. B, Quantification: $p<0.001$, ANOVA. regenerative neurotrophic factors (Hauk et al., 2008; Ahmed et al., 2010). However, reactive astrocytes also contribute to injury-induced ECM remodeling; altered synaptic connectivity in the retinal layers; and altered photoreceptor cellular organization, function, and synaptic connectivity (Fisher et al., 2005; Lewis et al., 2010; Luna et al., 2010; Kayama et al., 2011). Various proinflammatory stimuli, including lens injury, intravitreal injection of zymosan (macrophage activator) or stem cells, and intravitreal peripheral nerve grafting, can all reduce injuryinduced RGC death (Berry et al., 1996; Leon et al., 2000; Yin et al., 2003; Mead et al., 2013), presumably by modulating the nature of the inflammatory response. For example, after lens injury and intravitreal zymosan injection, retinal astrocytes and Müller cells release CNTF, which supports axon regeneration (Muller et al., 2007). Immunomodulation combined with endogenous or exogenous growth factors can enhance RGC regeneration synergistically (Kerschensteiner et al., 2003; Lorber et al., 2008). After incision-induced trauma to the retina, some types of inflammation appear to reduce retinal cell death and increase RGC axon regeneration (Berry et al., 2008). Immunosuppressive agents like corticosteroids have also been used to treat intermediate and posterior segment uveitis with some success. Corticosteroids can reduce inflammation and alleviate other structural complications. However, complete suppression of the immune system leads to secondary complications (Thiyagarajan et al., 2013) that may actually prohibit long-term recovery in the CNS. In general, inflammation due to retinal trauma promotes an M1-like phenotype, which decreases RGC survival and increases scarring (Cruz-Guilloty et al., 2013; He and Marneros, 2013), emphasizing the importance of identifying the type and the scope of the inflammatory response, as well as highlighting the need for readily available and versatile immunomodulatory therapeutic platforms.

Can ECM-based immunomodulatory devices fill this need in the CNS, for example by slowing or halting retinal disease progression? Increasingly, microglial activation is implicated in retinal disease pathogenesis, including glaucoma (Yuan and Neufeld, 2001), diabetic retinopathy (Zeng et al., 2008), age-related macular degeneration (AMD; Gupta et al., 2003), and retinitis pigmentosa (RP; Gupta et al., 2003), among others. Transplantation of human induced pluripotent stem cell-derived retinal cell types has been proposed as a potential treatment for AMD and RP. However, this treatment strategy needs to be optimized with regard to characterizing and preparing donor cells (Ramsden et al., 2013). Current clinical immunotherapies can inhibit microglial activity (Yrjänheikki et al., 1998). However, such strategies can also disrupt microglial regulation of CNS homeostasis (Edan et al., 2013). Thus, a more biocompatible immunotherapy like ECM may be advantageous under certain conditions alone or as an adjunct therapy. For example, in AMD, macrophages penetrate the interphotoreceptor matrix and polarize toward an M1-like phenotype, which is recognized as a key factor in dry AMD pathogenesis (CruzGuilloty et al., 2013). In retinal diseases, can ECM hydrogels be used to modulate microglial activation di- 
rectly or in combination by delivering other therapeutics in a natural, injectable, biodegradable device? And, if so, can sustained modulation be achieved in various diseases?

\section{ECM technology can mitigate secondary trauma}

Primary mechanical injuries are often followed by additional tissue destruction and expanded scarring due to the inflammatory response. In the visual system, secondary ocular trauma in the retina or in the optic nerve can rapidly increase the injury area and lead to increased vision loss. One of the most detrimental injury conditions is during warfare, where significant delays in ocular treatment are common. In modern warfare, blast injuries are the most common wounded-in-action injuries accounting for $\sim 60 \%$ of all injuries as of July 2009 , with up to $40 \%$ of blast injuries expressing concomitant eye injuries. To treat ocular trauma due to penetrating injuries and intraocular foreign bodies, the current standard of care requires a vitreoretinal service and a microsurgical operating suite, which is generally not possible on the battlefield or in Level III combat support hospitals. In a combat support hospital, patients do receive an eye evaluation and primary surgical repair by an experienced ophthalmologist (Weichel and Colyer, 2008), often within hours of injury. However, in cases where a microsurgical suite and a vitreoretinal service are required, patients typically experience a minimum 72-96 h delay before evacuation. These delays are during a critical period in the healing process since secondary inflammatory trauma can increase progressively and is often more damaging than the primary trauma. For example, secondary inflammatory responses to penetrating injuries can contribute to endophthalmitis, which can lead to vision and even eye loss (Lemley and Han, 2007), or proliferative vitreoretinopathy (PVR), which can result in progressive retinal traction, tears, and retinal detachment (Charteris, 1995). The molecular cascades leading to PVR are detectable within hours in rodent models of PVR (Wen et al., 1995; Ozaki et al., 2000; Penn et al., 2006), again emphasizing the need for therapies to suppress secondary inflammation, like ECM-based devices, which are safe, derived from renewable resources, and relatively inexpensive, and can be tailored to the nature and scope of the injury.

\section{ECM hydrogels are a highly tunable biologic platform}

To address this problem, ECM hydrogel technology is being developed in two platforms designed to rapidly mitigate secondary trauma in varied injuries. The first platform is an injectable hydrogel (Medberry et al., 2013) that can be injected into or around the eye, whereas the second platform is a convenient ECM and polymer biohybrid sheet (Hong et al., 2011). These technologies are designed to stabilize retinal or optic nerve injury, reduce scarring, and increase the potential for vision preservation. Both platforms are tunable, both mechanically and biochemically, to deliver drugs, cells, or other therapeutics in a biocompatible, immunomodulatory platform.

\section{ECM hydrogels}

ECM-based hydrogel scaffolds are advantageous because of their potential for minimally invasive delivery. Applying ECM technology to injured neural tissues has been limited, as previously reviewed (Meng et al., 2014), particularly in the CNS where intrinsic regenerative ability is low (Goldberg et al., 2002). However, a number of studies in spinal cord have shown that acellular ECM matrices can integrate within host spinal cords after traumatic brain injury and even improve motor function ( $\mathrm{Li}$ et al., 2012; Zhang et al., 2012; Liu et al., 2013). UBM has been shown to promote constructive cellular responses to and neuroprotection of injured brain tissues (Zhang et al., 2013). After injection into healthy brains, UBM did not increase microglia accumulation or astrocyte activation, or promote neuronal degeneration. After TBI in rats, UBM treatment reduced lesion volume and myelin disruption, and improved vestibulomotor function. However, cognitive recovery was undetected over the time points analyzed. Recently, Wang et al. (2013) reported similar results following TBI, showing that UBM decreased sensorimotor skill loss, indicating that ECM hydrogels may be a viable treatment option in CNS tissues. In cases of penetrating ocular trauma, local ECM hydrogel injection provides a biocompatible, tunable gel for filling acellular injuryinduced defects, recruiting and directing endogenous stem cell localization and differentiation, and modulating the immune system to promote positive tissue remodeling.

\section{ECM biohybrid bioscaffolds}

Biohybrid scaffolds confer several advantages to ECM hydrogels by combining the mechanical and biochemical tunability of an electrospun polymer sheet with the biologic properties of ECM (Hong et al., 2011; Fig. 5). In regenerative medicine approaches that require bioscaffolds with a higher tensile strength, hydrogels are disadvantageous due to rapid degradation rates and poor mechanical properties. The mechanical strength of ECM hydrogels can be improved by chemical crosslinking (Baiguera et al., 2014). However, crosslinking changes ECM composition, leading to increased risk of inflammation (Valentin et al., 2009), altered degradation rates and products, and altered biological efficacy and effects. Combining ECM hydrogels with a synthetic biocompatible and biodegradable polymer has been shown to be a viable option (Stankus et al., 2008; Yoon and Kim, 2010). Hong et al. (2011) used dual-stream electrospinning to blend synthetic poly(etherurethane urea) (PEUU) polymer and urinary bladder matrix. The resulting ECM biohybrid scaffolds have tunable degradation properties and tunable mechanical properties. For example, electrospun fibers can be aligned to direct axon growth. Kador et al. (2014) created a scaffold with aligned fibers by electrospinning, which guided retinal ganglion axon growth directionally. By integrating ECM hydrogels, biohybrid scaffolds possess higher biocompatibility compared with purely synthetic scaffold materials. In non-CNS models, biohybrid scaffolds have been shown to promote constructive tissue remodeling in ligament, heart, and body 


\section{Extracellular matrix sheets}

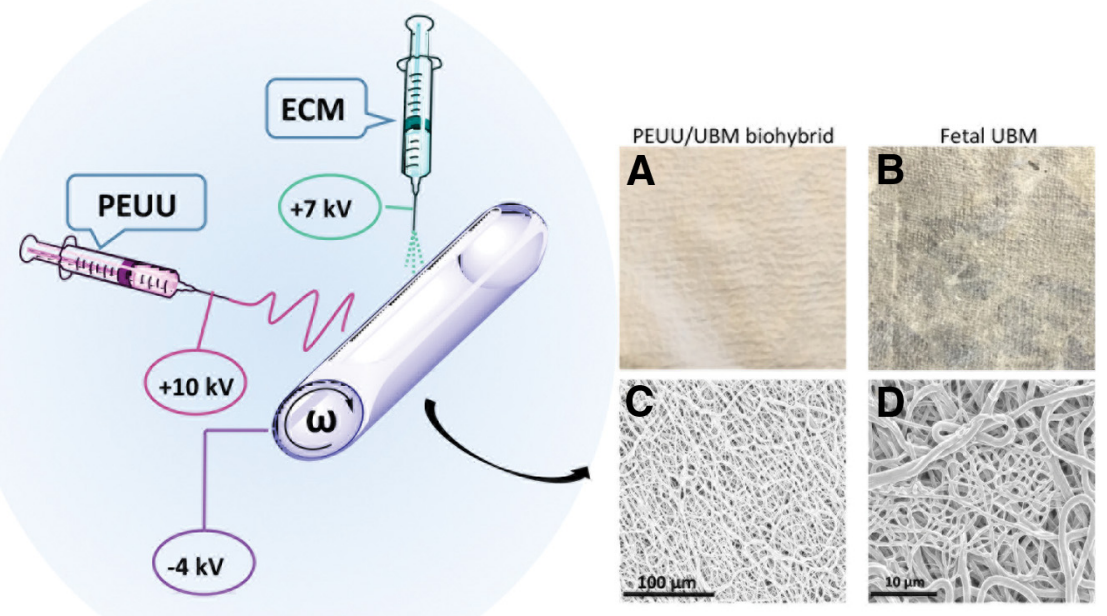

Figure 5. Extracellular matrix in two sheet forms. ECM biohybrid sheets can be made by dual-stream electrospinning. PEUU and ECM electrospinning setup consists of two syringe pumps and two high-voltage power supply units (not shown). A high positive voltage $(+7-10 \mathrm{kV})$ is used to charge the steel capillary containing the polymer or ECM solution, and a high negative voltage $(-4 \mathrm{kV})$ is used to charge the stainless steel mandrel $(\omega)$. The mandrel is rotated at $200 \mathrm{rpm}$ with a slow lateral translation over a distance of $15 \mathrm{~cm}$, $\boldsymbol{A}$, Yielding a tubular, uniform PEUU/ECM sheet. $\boldsymbol{B}$, Fetal urinary bladder sheet after vacuum pressing. $\boldsymbol{C}, \boldsymbol{D}$, Scanning electron microscopy showing the random fibers in the PEUU/ECM biohybrid wrap.

wall (Hong et al., 2011; Thayer et al., 2014; Jahnavi et al., 2015). In nervous system tissue repair scenarios, the ability to readily form biohybrid scaffolds into a suturable nerve wrap or a patch to protect exposed tissues makes ECM biohybrid scaffolds attractive devices for both mechanical and biochemical support.

\section{ECM hydrogels for cellular transplantation}

ECM hydrogels provide a tissue-specific, naturally derived platform for delivering transplanted cells in an injectable platform. Transplanting purified retinal progenitor cells or neural stem cells (NSCs) has emerged as a promising therapy for preserving visual function. Intravitreal or optic nerve injections of RGCs, RGC progenitors, or stem cells are minimally invasive and have been shown in some neurodegenerative disease models to be neuroprotective (Klassen et al., 2008; Eveleth, 2013). Transplanted RGCs or stem cells are hypothesized to slow retinal degeneration by modulating multiple prosurvival pathways simultaneously via locally secreted neurotrophic factors and/or via modulation of the intraocular microenvironment (Miyata et al., 2005; Hertz et al., 2014). And clinical trials have been performed to test these hypotheses (Ning et al., 2011). However, RGCs injected into the vitreous integrate randomly without the correct spatial and cellular organization. Moreover, although transplanted RGCs can extend long axons, their orientation is generally not directed toward the optic nerve head, a prerequisite for restoring RGC connectivity to the brain. Transplanting sheets of fetus-derived retinal progenitor cells subretinally can restore some vision in both animal models and humans. In Phase II clinical trials, visual acuity was improved in pa- tients with retinitis pigmentosa or macular degeneration (Seiler and Aramant, 2012), demonstrating that cellular transplantation strategies can preserve retinal function in cases where the ganglion cell connectivity to the brain is intact. Moreover, retinal sheets hold promise for replacing RGCs with the proper cellular organization in the retina. However, similar to single-cell RGC transplantation, retinal sheets cannot replace lost RGCs with the correct retinal and optic nerve organization, and thus cannot currently restore vision loss due to lost RGCs. By using CNS tissue-specific ECM hydrogels, stem or progenitor cells can be encapsulated and then injected precisely within a biocompatible matrix, which may offer greater potential for integration and preservation of function.

In other cases, ECM biohybrid sheets may provide a better option for delivering cells. For example, mesenchymal stem cells (MSCs) can modulate immune and inflammatory effects after injury in both the CNS and peripheral nervous systems (PNS). MSC delivery into the injury site can provide anti-inflammatory, immunomodulatory, and neuroprotective benefits. For example, in dogs with acute spinal cord injury, the injection of MSCs significantly improved functional recovery (Penha et al., 2014). However, further studies have shown these injections cause additional injury due to needle penetration, spinal cord motion during injection, creation of intraparenchymal pressure gradients, and hydrodynamic dissection, instilling deformed cell masses and possible cord ischemia (Donnelly et al., 2012). Other studies, using scaffolds, have shown that fibrin sheets incorporating MSCs demonstrate longitudinal alignment of MSCs and infiltration of host neurites, which are correlated with further improvement of functional outcomes (Hyatt et al., 2014). Several mechanisms 


\section{Using ECM to promote positive tissue remodeling}

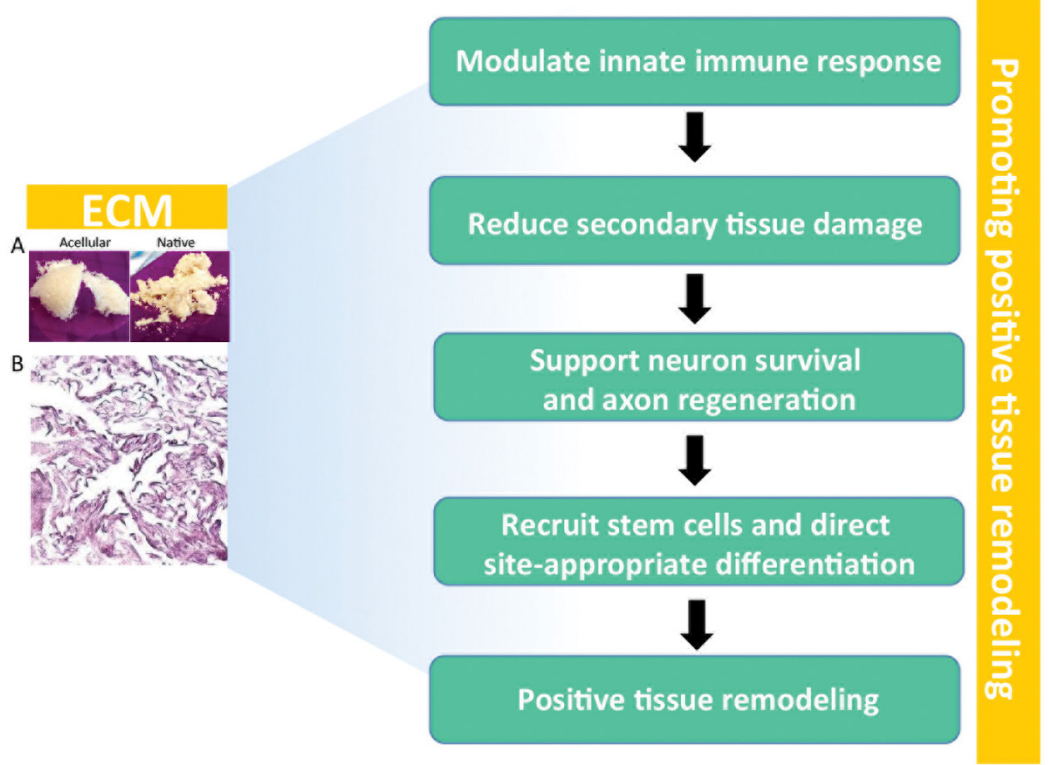

Figure 6. ECM technology can promote positive tissue remodeling by modulating several factors that contribute to the default healing response in the CNS.

have been proposed for the improved axonal regeneration seen after injecting MSCs, including paracrine effects due to the release of trophic factors, including BDNF, NGF, VEGF, FGF-2, TGF- $\beta$, and interferon gamma-1 (Mead et al., 2014). By incorporating mesenchymal stem cells into ECM biohybrid sheets, the neuroprotective potential of stem cells is combined with the immunomodulatory benefits of ECM. Moreover, incorporating stem cells into a polymer with tunable biodegradability provides more control over restricting the cells to a defined location, like subretinal implantation or as an optic nerve wrap, while permitting the soluble factors released from both stem cell and macrophage degradation of the ECM components, which have been shown in some systems to have positive synergistic effects with regard to tissue repair (Liu et al., 2011)

Can tissue-specific ECMs provide a more efficacious platform for stem or progenitor cell differentiation and integration? Numerous studies have shown that ECM bioscaffolds can direct site-appropriate cellular differentiation from both endogenous (Horne et al., 2010) and mesenchymal stem cell (Wang et al., 2010) sources. There are numerous examples of tissue-specific ECMs directing tissue-specific cellular phenotype differentiation and function. For example, cartilage-derived ECM can promote chondrogenic differentiation of adipose-derived stromal stem cells (Wang et al., 2014), while cardiac ECM can direct cardiac myocyte differentiation (Xu et al., 2014). Acellular spinal cord scaffolds can promote positive tissue remodeling in spinal cord injury models, similar to MSCs (Liu et al., 2013; Xue et al., 2013). Methods for decellularizing spinal cord (Guo et al., 2010), brain (DeQuach et al., 2011), and optic nerve (Crapo et al., 2012) have been developed from adult and even from fetal sources (Fig. 3).
Acelluar CNS ECM scaffolds retain neurosupportive proteins, growth factors in a three-dimensional scaffold. Compared with UBM, CNS-derived ECMs induced PC12 cell migration, while UBM inhibited migration (Crapo et al., 2012). Brain-derived ECM improved neurite growth of neural stem cells (Medberry et al., 2013) and neuronal differentiation of induced pluripotent stem cells. (Crapo et al., 2012). These studies suggest that ECM may provide tissue-specific advantages in CNS regenerative medicine applications and that ECM scaffolds in general may aid functional recovery after retinal disease.

\section{Non-tissue-specific ECMs can also promote positive CNS repair}

Acellular muscle ECM has been used to treat spinal cord hemi-sections in rats. With the help of its parallel tubule structure, sprouting axons grew the full length of the scaffold in a strikingly parallel and linear fashion (Zhang et al., 2012). Loaded with amniotic epithelial cells, acellular muscle scaffolds further promoted nerve fiber sprouting and remyelination, resulting in more functional recovery (Xue et al., 2013). Acellular vessels are also a candidate for nerve regeneration scaffolds. Acellular vessels were used as nerve conduits connecting the two stumps of injured peripheral nerves (Sun et al., 2011). Acellular PNS scaffolds may also be a good choice for optic nerve repair. Sciatic nerves were decellularized with different methods (Gao et al., 2014), and their function in nerve regeneration was evaluated ( $\mathrm{Li}$ et al., 2012; Gao et al., 2014). Schwann cells can support RGC axon growth, possibly due to neurotrophic factor secretion and/or the neurotrophic cell receptors on the membrane of Schwann cells (Baehr and Bunge, 1989; Hu et al., 
2005). Treating ECM with neurotrophic factors can also improve their ability in CNS regeneration (Li et al., 2012).

Cellular viability and retinal integration are improved by using various hydrogel materials, including hyaluronic acid (Gao et al., 2012, Carey et al., 2014), Matrigel (Sharp and Archer, 2015), alginate (Yang et al., 2015), collagen, (Cruz-Guilloty et al., 2013), and fibrin (Meng et al., 2014). Brain ECM hydrogels promoted neuronal differentiation of induced pluripotent stem cells better than Matrigelcoated surfaces (DeQuach et al., 2011). DeQuach et al. (2011) produced brain ECMs and found that neurons derived from human induced pluripotent stem cells plated on the brain matrix express neuronal markers and assume neuronal morphology. Crapo et al. (2014) showed that CNS-derived ECMs show higher ability in inducing neuron differentiation of neuronal stem cells compared with UBM. Liu et al. (2013) developed MSCs that loaded acelluar spinal cord ECM, which promoted long-distance axon regeneration in vivo. Moreover, UBM hydrogel has been used as a carrier for NSCs and injected into rodent brain. The transplants reduced neuron/tissue loss and white matter injury, and also significantly ameliorated motor, memory, and cognitive impairments (Wang et al., 2013). Stem cells delivered by UBM hydrogels in a murine stroke model distributed uniformly throughout the lesion cavity instead of integrating into the host parenchyma. Better distribution was associated with better primitive tissue formation (Bible et al., 2012).

\section{Conclusion}

ECM-derived hydrogels are natural, biocompatible devices that can modulate inflammation, attract and direct stem cell proliferation and differentiation, and serve as a tunable platform for delivering an almost unlimited combination of genetic, molecular, and cellular therapeutic factors. ECM bioscaffolds have been shown to reduce inflammation and scarring while improving positive tissue reconstruction in tissues throughout the body. We hypothesize that tissue-specific hydrogels can do the same in CNS tissues generally as well as specifically within the retina and the optic nerve (Fig. 6). Ultimately, a highly defined and targeted approach is desired to treat CNS injuries with specificity. Thus, future studies should include further characterization of the bioactive components in the ECM, how various ECM components impact the innate immune response, and, in turn, how soluble and nonsoluble factors act on other cells within the CNS, including the glia, primary neurons, and progenitor and stem cells.

\section{References}

Adair-Kirk TL, Senior RM (2008) Fragments of extracellular matrix as mediators of inflammation. Int J Biochem Cell Biol 40:1101-1110. CrossRef Medline

Agrawal V, Brown BN, Beattie AJ, Gilbert TW, Badylak SF (2009) Evidence of innervation following extracellular matrix scaffoldmediated remodelling of muscular tissues. J Tissue Eng Regen Med 3:590-600. CrossRef Medline

Agrawal V, Siu BF, Chao H, Hirschi KK, Raborn E, Johnson SA, Tottey S, Hurley KB, Medberry CJ, Badylak SF (2012) Partial characterization of the Sox $2+$ cell population in an adult murine model of digit amputation. Tissue Eng Part A 18:1454-1463. CrossRef Medline

Agrawal V, Tottey S, Johnson SA, Freund JM, Siu BF, Badylak SF (2011) Recruitment of progenitor cells by an extracellular matrix cryptic peptide in a mouse model of digit amputation. Tissue Eng Part A 17:2435-2443. CrossRef

Ahmed Z, Aslam M, Lorber B, Suggate EL, Berry M, Logan A (2010) Optic nerve and vitreal inflammation are both RGC neuroprotective but only the latter is RGC axogenic. Neurobiol Dis 37:441-454. CrossRef Medline

Badylak S, Meurling S, Chen M, Spievack A, Simmons-Byrd A (2000) Resorbable bioscaffold for esophageal repair in a dog model. $J$ Pediatr Surg 35:1097-1103. CrossRef Medline

Badylak SF (2004) Xenogeneic extracellular matrix as a scaffold for tissue reconstruction. Transpl Immunol 12:367-377. CrossRef Medline

Badylak SF (2007) The extracellular matrix as a biologic scaffold material. Biomaterials 28:3587-3593. CrossRef Medline

Badylak SF, Valentin JE, Ravindra AK, McCabe GP, Stewart-Akers AM (2008) Macrophage phenotype as a determinant of biologic scaffold remodeling. Tissue Eng Part A 14:1835-1842. CrossRef Medline

Badylak SF, Vorp DA, Spievack AR, Simmons-Byrd A, Hanke J, Freytes DO, Thapa A, Gilbert TW, Nieponice A (2005) Esophageal reconstruction with ECM and muscle tissue in a dog model. J Surg Res 128:87-97. CrossRef Medline

Baehr M, Bunge RP (1989) Functional status influences the ability of Schwann cells to support adult rat retinal ganglion cell survival and axonal regrowth. Exp Neurol 106:27-40. Medline

Baiguera S, Del Gaudio C, Lucatelli E, Kuevda E, Boieri M, Mazzanti B, Bianco A, Macchiarini P (2014) Electrospun gelatin scaffolds incorporating rat decellularized brain extracellular matrix for neural tissue engineering. Biomaterials 35:1205-1214. CrossRef Medline

Bartus K, James ND, Didangelos A, Bosch KD, Verhaagen J, YáñezMuñoz RJ, Rogers JH, Schneider BL, Muir EM, Bradbury EJ (2014) Large-scale chondroitin sulfate proteoglycan digestion with chondroitinase gene therapy leads to reduced pathology and modulates macrophage phenotype following spinal cord contusion injury. J Neurosci 34:4822-4836. CrossRef Medline

Berkelaar M, Clarke DB, Wang YC, Bray GM, Aguayo AJ (1994) Axotomy results in delayed death and apoptosis of retinal ganglion cells in adult rats. J Neurosci 14:4368-4374. Medline

Berry M, Ahmed Z, Lorber B, Douglas M, Logan A (2008) Regeneration of axons in the visual system. Restor Neurol Neurosci 26: 147-174. Medline

Berry M, Carlile J, Hunter A (1996) Peripheral nerve explants grafted into the vitreous body of the eye promote the regeneration of retinal ganglion cell axons severed in the optic nerve. J Neurocytol 25:147-170. Medline

Berthiaume F, Moghe PV, Toner M, Yarmush ML (1996) Effect of extracellular matrix topology on cell structure, function, and physiological responsiveness: hepatocytes cultured in a sandwich configuration. FASEB J 10:1471-1484.

Bible E, Dell'Acqua F, Solanky B, Balducci A, Crapo PM, Badylak SF, Ahrens ET, Modo M (2012) Non-invasive imaging of transplanted human neural stem cells and ECM scaffold remodeling in the stroke-damaged rat brain by (19)F- and diffusion-MRI. Biomaterials 33:2858-2871. CrossRef

Bissell MJ, Barcellos-Hoff MH (1987) The influence of extracellular matrix on gene expression: is structure the message? J Cell Sci Suppl 8:327-343. Medline

Bray GM, Vidal-Sanz M, Aguayo AJ (1987) Regeneration of axons from the central nervous system of adult rats. Prog Brain Res 71:373-379. Medline

Brennan EP, Reing J, Chew D, Myers-Irvin JM, Young EJ, Badylak SF (2006) Antibacterial activity within degradation products of biological scaffolds composed of extracellular matrix. Tissue Eng 12:2949-2955. CrossRef Medline

Brennan EP, Tang XH, Stewart-Akers AM, Gudas LJ, Badylak SF (2008) Chemoattractant activity of degradation products of fetal 
and adult skin extracellular matrix for keratinocyte progenitor cells. J Tissue Eng Regen Med 2:491-498. CrossRef Medline

Brinkmann V, Zychlinsky A (2012) Neutrophil extracellular traps: is immunity the second function of chromatin? J Cell Biol 198:773783. CrossRef Medline

Brown BN, Londono R, Tottey S, Zhang L, Kukla KA, Wolf MT, Daly KA, Reing JE, Badylak SF (2012) Macrophage phenotype as a predictor of constructive remodeling following the implantation of biologically derived surgical mesh materials. Acta Biomater 8:978987. CrossRef Medline

Brown BN, Valentin JE, Stewart-Akers AM, McCabe GP, Badylak SF (2009) Macrophage phenotype and remodeling outcomes in response to biologic scaffolds with and without a cellular component. Biomaterials 30:1482-1491. CrossRef Medline

Butt AM, Pugh M, Hubbard P, James G (2004) Functions of optic nerve glia: axoglial signalling in physiology and pathology. Eye 18:1110-1121. CrossRef Medline

Carey LE, Dearth CL, Johnson SA, Londono R, Medberry CJ, Daly KA, Badylak SF (2014) In vivo degradation of 14C-labeled porcine dermis biologic scaffold. Biomaterials 35:8297-8304. CrossRef Medline

Charteris DG (1995) Proliferative vitreoretinopathy: pathobiology, surgical management, and adjunctive treatment. $\mathrm{Br} \mathrm{J}$ Ophthalmol 79:953-960. Medline

Cherry JD, Olschowka JA, O'Banion MK (2014) Neuroinflammation and M2 microglia: the good, the bad, and the inflamed. J Neuroinflammation 11:98. CrossRef Medline

Cho MS, Rinker BD, Weber RV, Chao JD, Ingari JV, Brooks D, Buncke GM (2012) Functional outcome following nerve repair in the upper extremity using processed nerve allograft. J Hand Surg Am 37:2340-2349. CrossRef Medline

Crapo PM, Medberry CJ, Reing JE, Tottey S, van der Merwe Y, Jones KE, Badylak SF (2012) Biologic scaffolds composed of central nervous system extracellular matrix. Biomaterials 33:35393547. CrossRef Medline

Crapo PM, Tottey S, Slivka PF, Badylak SF (2014) Effects of biologic scaffolds on human stem cells and implications for CNS tissue engineering. Tissue Eng Part A 20:313-323. CrossRef Medline

Crisan M, Yap S, Casteilla L, Chen CW, Corselli M, Park TS, Andriolo G, Sun B, Zheng B, Zhang L, Norotte C, Teng PN, Traas J, Schugar R, Deasy BM, Badylak S, Buhring HJ, Giacobino JP, Lazzari L, Huard J, et al (2008) A perivascular origin for mesenchymal stem cells in multiple human organs. Cell Stem Cell 3:301-313. CrossRef Medline

Cruz-Guilloty F, Saeed AM, Echegaray JJ, Duffort S, Ballmick A, Tan Y, Betancourt M, Viteri E, Ramkhellawan GC, Ewald E, Feuer W, Huang D, Wen R, Hong L, Wang H, Laird JM, Sene A, Apte RS, Salomon RG, Hollyfield JG, Perez VL (2013) Infiltration of proinflammatory $\mathrm{m} 1$ macrophages into the outer retina precedes damage in a mouse model of age-related macular degeneration. Int $\mathrm{J}$ Inflam 2013:503725. CrossRef

Davis GE, Bayless KJ, Davis MJ, Meininger GA (2000) Regulation of tissue injury responses by the exposure of matricryptic sites within extracellular matrix molecules. Am J Pathol 156:1489-1498. CrossRef Medline

de Lima S, Koriyama Y, Kurimoto T, Oliveira JT, Yin Y, Li Y, Gilbert HY, Fagiolini M, Martinez AM, Benowitz L (2012) Full-length axon regeneration in the adult mouse optic nerve and partial recovery of simple visual behaviors. Proc Natl Acad Sci U S A 109:9149-9154. CrossRef Medline

DeQuach JA, Yuan SH, Goldstein LS, Christman KL (2011) Decellularized porcine brain matrix for cell culture and tissue engineering scaffolds. Tissue Eng Part A 17:2583-2592. CrossRef

Didangelos A, Iberl M, Vinsland E, Bartus K, Bradbury EJ (2014) Regulation of IL-10 by chondroitinase ABC promotes a distinct immune response following spinal cord injury. J Neurosci 34: 16424-16432. CrossRef Medline

Donnelly DJ, Popovich PG (2008) Inflammation and its role in neuroprotection, axonal regeneration and functional recovery after spinal cord injury. Exp Neurol 209:378-388. CrossRef Medline
Donnelly E, Lamanna J, Boulis N (2012) Stem cell therapy for the spinal cord. Stem Cell Res Ther 3:24. CrossRef Medline

Edan RA, Luqmani YA, Masocha W (2013) COL-3, a chemically modified tetracycline, inhibits lipopolysaccharide-induced microglia activation and cytokine expression in the brain. PLoS One 8:e57827. CrossRef Medline

Eveleth DD (2013) Cell-based therapies for ocular disease. J Ocul Pharmacol Ther 29:844-854. CrossRef Medline

Fisher SK, Lewis GP, Linberg KA, Verardo MR (2005) Cellular remodeling in mammalian retina: results from studies of experimental retinal detachment. Prog Retin Eye Res 24:395-431. CrossRef Medline

Gao H, Zhang HL, Shou J, Chen L, Shen Y, Tang Q, Huang J, Zhu J (2012) Towards retinal ganglion cell regeneration. Regen Med 7:865-875. CrossRef Medline

Gao S, Zheng Y, Cai Q, Yao W, Wang J, Zhang P, Wang X (2014) Comparison of morphology and biocompatibility of acellular nerve scaffolds processed by different chemical methods. J Mater Sci Mater Med 25:1283-1291. CrossRef Medline

Gilbert TW, Sellaro TL, Badylak SF (2006) Decellularization of tissues and organs. Biomaterials 27:3675-3683. CrossRef Medline

Giulian D, Robertson C (1990) Inhibition of mononuclear phagocytes reduces ischemic injury in the spinal cord. Ann Neurol 27:33-42. CrossRef Medline

Godwin JW, Pinto AR, Rosenthal NA (2013) Macrophages are required for adult salamander limb regeneration. Proc Natl Acad Sci U S A 110:9415-9420. CrossRef Medline

Godwin JW, Rosenthal N (2014) Scar-free wound healing and regeneration in amphibians: immunological influences on regenerative success. Differentiation 87:66-75. CrossRef Medline

Goldberg JL, Klassen MP, Hua Y, Barres BA (2002) Amacrinesignaled loss of intrinsic axon growth ability by retinal ganglion cells. Science 296:1860-1864. CrossRef Medline

Gris D, Marsh DR, Oatway MA, Chen Y, Hamilton EF, Dekaban GA, Weaver LC (2004) Transient blockade of the CD11d/CD18 integrin reduces secondary damage after spinal cord injury, improving sensory, autonomic, and motor function. J Neurosci 24:40434051. CrossRef Medline

Guo SZ, Ren XJ, Wu B, Jiang T (2010) Preparation of the acellular scaffold of the spinal cord and the study of biocompatibility. Spinal Cord 48:576-581. CrossRef Medline

Gupta N, Brown KE, Milam AH (2003) Activated microglia in human retinitis pigmentosa, late-onset retinal degeneration, and agerelated macular degeneration. Exp Eye Res 76:463-471. Medline

Haan N, Zhu B, Wang J, Wei X, Song B (2015) Crosstalk between macrophages and astrocytes affects proliferation, reactive phenotype and inflammatory response, suggesting a role during reactive gliosis following spinal cord injury. J Neuroinflammmation 12:109. CrossRef Medline

Hains BC, Waxman SG (2006) Activated microglia contribute to the maintenance of chronic pain after spinal cord injury. J Neurosci 26:4308-4317. CrossRef Medline

Hao NB, Lü MH, Fan YH, Cao YL, Zhang ZR, Yang SM (2012) Macrophages in tumor microenvironments and the progression of tumors. Clin Dev Immunol 2012:948098. CrossRef Medline

Hauk TG, Müller A, Lee J, Schwendener R, Fischer D (2008) Neuroprotective and axon growth promoting effects of intraocular inflammation do not depend on oncomodulin or the presence of large numbers of activated macrophages. Exp Neurol 209:469482. CrossRef Medline

He L, Marneros AG (2013) Macrophages are essential for the early wound healing response and the formation of a fibrovascular scar. Am J Pathol 182:2407-2417. CrossRef Medline

Hertz J, Qu B, Hu Y, Patel RD, Valenzuela DA, Goldberg JL (2014) Survival and integration of developing and progenitor-derived retinal ganglion cells following transplantation. Cell Transplant 23: 855-872. CrossRef Medline

Hodde JP, Record RD, Liang HA, Badylak SF (2001) Vascular endothelial growth factor in porcine-derived extracellular matrix. Endothelium 8:11-24. Medline 
Hong Y, Huber A, Takanari K, Amoroso NJ, Hashizume R, Badylak SF, Wagner WR (2011) Mechanical properties and in vivo behavior of a biodegradable synthetic polymer microfiber-extracellular matrix hydrogel biohybrid scaffold. Biomaterials 32:3387-3394. CrossRef Medline

Horn KP, Busch SA, Hawthorne AL, van Rooijen N, Silver J (2008) Another barrier to regeneration in the CNS: activated macrophages induce extensive retraction of dystrophic axons through direct physical interactions. J Neurosci 28:9330-9341. CrossRef

Horne MK, Nisbet DR, Forsythe JS, Parish CL (2010) Threedimensional nanofibrous scaffolds incorporating immobilized BDNF promote proliferation and differentiation of cortical neural stem cells. Stem Cells Dev 19:843-852. CrossRef

Hu Y, Leaver SG, Plant GW, Hendriks WTJ, Niclou SP, Verhaagen J, Harvey AR, Cui Q (2005) Lentiviral-mediated transfer of CNTF to Schwann cells within reconstructed peripheral nerve grafts enhances adult retinal ganglion cell survival and axonal regeneration. Mol Ther 11:906-915. CrossRef

Huang KF, Hsu WC, Chiu WT, Wang JY (2012) Functional improvement and neurogenesis after collagen-GAG matrix implantation into surgical brain trauma. Biomaterials 33:2067-2075. CrossRef Medline

Hyatt AJT, Wang D, van Oterendorp C, Fawcett JW, Martin KR (2014) Mesenchymal stromal cells integrate and form longitudinallyaligned layers when delivered to injured spinal cord via a novel fibrin scaffold. Neurosci Lett 569:12-17. CrossRef

Jahnavi S, Kumary TV, Bhuvaneshwar GS, Natarajan TS, Verma RS (2015) Engineering of a polymer layered bio-hybrid heart valve scaffold. Mater Sci Eng C Mater Biol Appl 51:263-273. CrossRef Medline

Jones LL, Margolis RU, Tuszynski MH (2003) The chondroitin sulfate proteoglycans neurocan, brevican, phosphacan, and versican are differentially regulated following spinal cord injury. Exp Neurol 182:399-411. Medline

Kador KE, Alsehli HS, Zindell AN, Lau LW, Andreopoulos FM, Watson BD, Goldberg JL (2014) Retinal ganglion cell polarization using immobilized guidance cues on a tissue-engineered scaffold. Acta Biomater 10:4939-4946. CrossRef Medline

Karabekmez FE, Duymaz A, Moran SL (2009) Early clinical outcomes with the use of decellularized nerve allograft for repair of sensory defects within the hand. Hand (N Y) 4:245-249. CrossRef Medline

Kawamura K, Komohara Y, Takaishi K, Katabuchi H, Takeya M (2009) Detection of M2 macrophages and colony-stimulating factor 1 expression in serous and mucinous ovarian epithelial tumors. Pathol Int 59:300-305. CrossRef Medline

Kayama M, Nakazawa T, Thanos A, Morizane Y, Murakami Y, Theodoropoulou S, Abe T, Vavvas D, Miller JW (2011) Heat shock protein 70 (HSP70) is critical for the photoreceptor stress response after retinal detachment via modulating anti-apoptotic Akt kinase. Am J Pathol 178:1080-1091. CrossRef Medline

Keane TJ, Londono R, Turner NJ, Badylak SF (2012) Consequences of ineffective decellularization of biologic scaffolds on the host response. Biomaterials 33:1771-1781. CrossRef Medline

Kerschensteiner M, Stadelmann C, Dechant G, Wekerle H, Hohlfeld R (2003) Neurotrophic cross-talk between the nervous and immune systems: implications for neurological diseases. Ann Neurol 53:292-304. CrossRef Medline

Khaing ZZ, Milman BD, Vanscoy JE, Seidlits SK, Grill RJ, Schmidt CE (2011) High molecular weight hyaluronic acid limits astrocyte activation and scar formation after spinal cord injury. J Neural Eng 8:046033. CrossRef Medline

Kigerl KA, Gensel JC, Ankeny DP, Alexander JK, Donnelly DJ, Popovich PG (2009) Identification of two distinct macrophage subsets with divergent effects causing either neurotoxicity or regeneration in the injured mouse spinal cord. J Neurosci 29:13435-13444. CrossRef Medline

Klassen H, Warfvinge K, Schwartz PH, Kiilgaard JF, Shamie N, Jiang C, Samuel M, Scherfig E, Prather RS, Young MJ (2008) Isolation of progenitor cells from GFP-transgenic pigs and transplantation to the retina of allorecipients. Cloning Stem Cells 10:391-402. CrossRef Medline

Koh TJ, DiPietro LA (2011) Inflammation and wound healing: the role of the macrophage. Expert Rev Mol Med 13:e23. CrossRef Medline

Kurimoto T, Yin Y, Omura K, Gilbert HY, Kim D, Cen LP, Moko L, Kugler S, Benowitz LI (2010) Long-distance axon regeneration in the mature optic nerve: contributions of oncomodulin, CAMP, and pten gene deletion. J Neurosci 30:15654-15663. CrossRef

Lathrop KL, Steketee MB (2013) Mitochondrial dynamics in retinal ganglion cell axon regeneration and growth cone guidance. J Ocul Biol 1:9. Medline

Lemley CA, Han DP (2007) Endophthalmitis: a review of current evaluation and management. Retina 27:662-680. CrossRef Medline

Leon S, Yin Y, Nguyen J, Irwin N, Benowitz LI (2000) Lens injury stimulates axon regeneration in the mature rat optic nerve. $J$ Neurosci 20:4615-4626. Medline

Lewis GP, Chapin EA, Luna G, Linberg KA, Fisher SK (2010) The fate of Müller's glia following experimental retinal detachment: nuclear migration, cell division, and subretinal glial scar formation. Mol Vis 16:1361-1372. Medline

Li C, Zhang X, Cao R, Yu B, Liang H, Zhou M, Li D, Wang Y, Liu E (2012) Allografts of the acellular sciatic nerve and brain-derived neurotrophic factor repair spinal cord injury in adult rats. PLoS One 7:e42813. CrossRef Medline

Lin CM, Lin JW, Chen YC, Shen HH, Wei L, Yeh YS, Chiang YH, Shih R, Chiu PL, Hung KS, Yang LY, Chiu WT (2009) Hyaluronic acid inhibits the glial scar formation after brain damage with tissue loss in rats. Surg Neurol 72 [Suppl2]:S50-S54. CrossRef Medline

Liu J, Chen J, Liu B, Yang C, Xie D, Zheng X, Xu S, Chen T, Wang L, Zhang Z, Bai X, Jin D (2013) Acellular spinal cord scaffold seeded with mesenchymal stem cells promotes long-distance axon regeneration and functional recovery in spinal cord injured rats. J Neurol Sci 325:127-136. CrossRef Medline

Liu S, Zhang H, Zhang X, Lu W, Huang X, Xie H, Zhou J, Wang W, Zhang Y, Liu Y, Deng Z, Jin Y (2011) Synergistic angiogenesis promoting effects of extracellular matrix scaffolds and adiposederived stem cells during wound repair. Tissue Eng Part A 17:725739. CrossRef Medline

Lorber B, Berry M, Logan A (2008) Different factors promote axonal regeneration of adult rat retinal ganglion cells after lens injury and intravitreal peripheral nerve grafting. J Neurosci Res 86:894-903. CrossRef Medline

Luna G, Lewis GP, Banna CD, Skalli O, Fisher SK (2010) Expression profiles of nestin and synemin in reactive astrocytes and Müller cells following retinal injury: a comparison with glial fibrillar acidic protein and vimentin. Mol Vis 16:2511-2523. Medline

Mansour-Robaey S, Clarke DB, Wang YC, Bray GM, Aguayo AJ (1994) Effects of ocular injury and administration of brain-derived neurotrophic factor on survival and regrowth of axotomized retinal ganglion cells. Proc Natl Acad Sci U S A 91:1632-1636. Medline

Mantovani A, Sica A, Sozzani S, Allavena P, Vecchi A, Locati M (2004) The chemokine system in diverse forms of macrophage activation and polarization. Trends Immunol 25:677-686. CrossRef Medline

Martinez FO, Gordon S (2014) The M1 and M2 paradigm of macrophage activation: time for reassessment. F1000Prime Rep 6:13. CrossRef Medline

McDevitt CA, Wildey GM, Cutrone RM (2003) Transforming growth factor-beta1 in a sterilized tissue derived from the pig small intestine submucosa. J Biomed Mater Res A 67:637-640. CrossRef

McKeon RJ, Jurynec MJ, Buck CR (1999) The chondroitin sulfate proteoglycans neurocan and phosphacan are expressed by reactive astrocytes in the chronic CNS glial scar. J Neurosci 19:1077810788. Medline

Mead B, Logan A, Berry M, Leadbeater W, Scheven BA (2013) Intravitreally transplanted dental pulp stem cells promote neuroprotection and axon regeneration of retinal ganglion cells after 
optic nerve injury. Invest Ophthalmol Vis Sci 54:7544-7556. CrossRef Medline

Mead B, Logan A, Berry M, Leadbeater W, Scheven BA (2014) Paracrine-mediated neuroprotection and neuritogenesis of axotomised retinal ganglion cells by human dental pulp stem cells: comparison with human bone marrow and adipose-derived mesenchymal stem cells. PLoS One 9:e109305. CrossRef Medline

Medberry CJ, Crapo PM, Siu BF, Carruthers CA, Wolf MT, Nagarkar SP, Agrawal V, Jones KE, Kelly J, Johnson SA, Velankar SS, Watkins SC, Modo M, Badylak SF (2013) Hydrogels derived from central nervous system extracellular matrix. Biomaterials 34:10331040. CrossRef Medline

Medberry CJ, Tottey S, Jiang H, Johnson SA, Badylak SF (2012) Resistance to infection of five different materials in a rat body wall model. J Surg Res 173:38-44. CrossRef Medline

Meng F, Modo M, Badylak SF (2014) Biologic scaffold for CNS repair. Regen Med 9:367-383. CrossRef Medline

Miyata T, lizasa H, Sai Y, Fujii J, Terasaki T, Nakashima E (2005) Platelet-derived growth factor-BB (PDGF-BB) induces differentiation of bone marrow endothelial progenitor cell-derived cell line TR-BME2 into mural cells, and changes the phenotype. J Cell Physiol 204:948-955. CrossRef Medline

Mokarram N, Merchant A, Mukhatyar V, Patel G, Bellamkonda RV (2012) Effect of modulating macrophage phenotype on peripheral nerve repair. Biomaterials 33:8793-8801. CrossRef Medline

Mosser DM, Edwards JP (2008) Exploring the full spectrum of macrophage activation. Nat Rev Immunol 8:958-969. CrossRef Medline

Muller A, Hauk TG, Fischer D (2007) Astrocyte-derived CNTF switches mature RGCs to a regenerative state following inflammatory stimulation. Brain 130:3308-3320. CrossRef

National Federation of the Blind (2013) Blindness statistics. Baltimore, MD: National Federation of the Blind.

Nelson CM, Bissell MJ (2006) Of extracellular matrix, scaffolds, and signaling: tissue architecture regulates development, homeostasis, and cancer. Annu Rev Cell Dev Biol 22:287-309. CrossRef Medline

Ning B, Zhang A, Song H, Gong W, Ding Y, Guo S, Zhao Y, Jiang J, Jia T (2011) Recombinant human erythropoietin prevents motor neuron apoptosis in a rat model of cervical sub-acute spinal cord compression. Neurosci Lett 490:57-62. CrossRef

Ozaki S, Radeke MJ, Anderson DH (2000) Rapid upregulation of fibroblast growth factor receptor 1 (flg) by rat photoreceptor cells after injury. Invest Ophthalmol Vis Sci 41:568-579. Medline

Pascolini D, Mariotti SP (2012) Global estimates of visual impairment: 2010. Br J Ophthalmol 96:614-618. CrossRef Medline

Penha EM, Meira CS, Guimarães ET, Mendonça MV, Gravely FA, Pinheiro CM, Pinheiro TM, Barrouin-Melo SM, Ribeiro-Dos-Santos R, Soares MB (2014) Use of autologous mesenchymal stem cells derived from bone marrow for the treatment of naturally injured spinal cord in dogs. Stem Cells Int 2014:437521. CrossRef Medline

Penn JS, McCollum GW, Barnett JM, Werdich XQ, Koepke KA, Rajaratnam VS (2006) Angiostatic effect of penetrating ocular injury: role of pigment epithelium-derived factor. Invest Ophthalmol Vis Sci 47:405-414. CrossRef Medline

Perniconi B, Costa A, Aulino P, Teodori L, Adamo S, Coletti D (2011) The pro-myogenic environment provided by whole organ scale acellular scaffolds from skeletal muscle. Biomaterials 32:78707882. CrossRef

Popovich PG, Longbrake EE (2008) Can the immune system be harnessed to repair the CNS? Nat Rev Neurosci 9:481-493. CrossRef Medline

Ramsden CM, Powner MB, Carr AJ, Smart MJ, da Cruz L, Coffey PJ (2013) Stem cells in retinal regeneration: past, present and future. Development 140:2576-2585. CrossRef Medline

Reing JE, Zhang L, Myers-Irvin J, Cordero KE, Freytes DO, HeberKatz E, Bedelbaeva K, McIntosh D, Dewilde A, Braunhut SJ, Badylak SF (2009) Degradation products of extracellular matrix affect cell migration and proliferation. Tissue Eng Part A 15:605614. CrossRef Medline

National Center for Biotechnology Information (1997) Pieces of eight: bioactive fragments of extracellular proteins as regulators of angiogenesis. Trends Cell Biol 7:182-186. CrossRef

Schnell L, Fearn S, Klassen H, Schwab ME, Perry VH (1999) Acute inflammatory responses to mechanical lesions in the CNS: differences between brain and spinal cord. Eur J Neurosci 11:36483658. Medline

Schwab ME (2010) Functions of Nogo proteins and their receptors in the nervous system. Nat Rev Neurosci 11:799-811. CrossRef Medline

Seiler MJ, Aramant RB (2012) Cell replacement and visual restoration by retinal sheet transplants. Prog Retin Eye Res 31:661-687. CrossRef Medline

Sharp WW, Archer SL (2015) Mitochondrial dynamics in cardiovascular disease: fission and fusion foretell form and function. $\mathrm{J} \mathrm{Mol}$ Med 93:225-228. CrossRef Medline

Shechter R, London A, Varol C, Raposo C, Cusimano M, Yovel G, Rolls A, Mack M, Pluchino S, Martino G, Jung S, Schwartz M (2009) Infiltrating blood-derived macrophages are vital cells playing an anti-inflammatory role in recovery from spinal cord injury in mice. PLoS Med 6:e1000113. CrossRef Medline

Shechter R, Miller O, Yovel G, Rosenzweig N, London A, Ruckh J, Kim KW, Klein E, Kalchenko V, Bendel P, Lira SA, Jung S, Schwartz M (2013) Recruitment of beneficial M2 macrophages to injured spinal cord is orchestrated by remote brain choroid plexus. Immunity 38:555-569. CrossRef Medline

Sica A, Mantovani A (2012) Macrophage plasticity and polarization: in vivo veritas. J Clin Invest 122:787-795. CrossRef Medline

Sica A, Schioppa T, Mantovani A, Allavena P (2006) Tumourassociated macrophages are a distinct M2 polarised population promoting tumour progression: potential targets of anti-cancer therapy. Eur J Cancer 42:717-727. CrossRef Medline

Sicari BM, Johnson SA, Siu BF, Crapo PM, Daly KA, Jiang H, Medberry CJ, Tottey S, Turner NJ, Badylak SF (2012a) The effect of source animal age upon the in vivo remodeling characteristics of an extracellular matrix scaffold. Biomaterials 33:5524-5533. CrossRef Medline

Sicari BM, Agrawal V, Siu BF, Medberry CJ, Dearth CL, Turner NJ, Badylak SF (2012b) A murine model of volumetric muscle loss and a regenerative medicine approach for tissue replacement. Tissue Eng Part A 18:1941-1948. CrossRef Medline

Silver J, Miller JH (2004) Regeneration beyond the glial scar. Nat Rev Neurosci 5:146-156. CrossRef Medline

Sipperley JO, Quigley HA, Gass DM (1978) Traumatic retinopathy in primates. The explanation of commotio retinae. Arch Ophthalmol 96:2267-2273. Medline

Soares HD, Hicks RR, Smith D, McIntosh TK (1995) Inflammatory leukocytic recruitment and diffuse neuronal degeneration are separate pathological processes resulting from traumatic brain injury. J Neurosci 15:8223-8233.

Stankus JJ, Freytes DO, Badylak SF, Wagner WR (2008) Hybrid nanofibrous scaffolds from electrospinning of a synthetic biodegradable elastomer and urinary bladder matrix. J Biomater Sci Polym Ed 19:635-652. CrossRef Medline

Sun F, Zhou K, Mi WJ, Qiu JH (2011) Combined use of decellularized allogeneic artery conduits with autologous transdifferentiated adipose-derived stem cells for facial nerve regeneration in rats. Biomaterials 32:8118-8128. CrossRef Medline

Tang S, Qiu J, Nikulina E, Filbin MT (2001) Soluble myelin-associated glycoprotein released from damaged white matter inhibits axonal regeneration. Mol Cell Neurosci 18:259-269. CrossRef Medline

Thayer PS, Dimling AF, PlessI DS, Hahn MR, Guelcher SA, Dahlgren LA, Goldstein AS (2014) Cellularized cylindrical fiber/hydrogel composites for ligament tissue engineering. Biomacromolecules 15:75-83. CrossRef Medline

Thiyagarajan M, Gonzales XF, Anderson H (2013) Regulated cellular exposure to non-thermal plasma allows preferentially directed 
apoptosis in acute monocytic leukemia cells. Stud Health Technol Inform 184:436-442. Medline

Trimmer PA, Wunderlich RE (1990) Changes in astroglial scar formation in rat optic-nerve as a function of development. J Comp Neurol 296:359-378. CrossRef Medline

Turner JE, Blair JR, Chappell ET (1986) Peripheral nerve implantation into a penetrating lesion of the eye: stimulation of the damaged retina. Brain Res 376:246-254. Medline

Turner NJ, Badylak JS, Weber DJ, Badylak SF (2012) Biologic scaffold remodeling in a dog model of complex musculoskeletal injury. J Surg Res 176:490-502. CrossRef

Turner NJ, Badylak SF (2013) Biologic scaffolds for musculotendinous tissue repair. Eur Cell Mater 25:130-143. Medline

Valentin JE, Stewart-Akers AM, Gilbert TW, Badylak SF (2009) Macrophage participation in the degradation and remodeling of extracellular matrix scaffolds. Tissue Eng Part A 15:1687-1694. CrossRef Medline

Valentin JE, Turner NJ, Gilbert TW, Badylak SF (2010) Functional skeletal muscle formation with a biologic scaffold. Biomaterials 31:7475-7484. CrossRef Medline

Vasudevan S, Huang J, Botterman B, Matloub HS, Keefer E, Cheng J (2014) Detergent-free decellularized nerve grafts for long-gap peripheral nerve reconstruction. Plast Reconstr Surg Glob Open 2:e201. CrossRef Medline

Vazquez-Chona F, Song BK, Geisert EE Jr (2004) Temporal changes in gene expression after injury in the rat retina. Invest Ophthalmol Vis Sci 45:2737-2746. CrossRef Medline[Mismatch]

Vidal-Sanz M, Bray GM, Villegas-Perez MP, Thanos S, Aguayo AJ (1987) Axonal regeneration and synapse formation in the superior colliculus by retinal ganglion cells in the adult rat. $\mathrm{J}$ Neurosci 7:2894-2909.

Wang JY, Liou AK, Ren ZH, Zhang L, Brown BN, Cui XT, Badylak SF, Cai YN, Guan YQ, Leak RK, Chen J, Ji X, Chen L (2013) Neurorestorative effect of urinary bladder matrix-mediated neural stem cell transplantation following traumatic brain injury in rats. CNS Neurol Disord Drug Targets 12:413-425. Medline

Wang L, Wang ZH, Shen CY, You ML, Xiao JF, Chen GQ (2010) Differentiation of human bone marrow mesenchymal stem cells grown in terpolyesters of 3-hydroxyalkanoates scaffolds into nerve cells. Biomaterials 31:1691-1698. CrossRef Medline

Wang T, Lai JH, Han LH, Tong X, Yang F (2014) Chondrogenic differentiation of adipose-derived stromal cells in combinatorial hydrogels containing cartilage matrix proteins with decoupled mechanical stiffness. Tissue Eng Part A 20:2131-2139. CrossRef Medline

Weichel ED, Colyer MH (2008) Combat ocular trauma and systemic injury. Current Opin Ophthalmol 19:519-525. CrossRef Medline
Wen R, Song Y, Cheng T, Matthes MT, Yasumura D, LaVail MM, Steinberg RH (1995) Injury-induced upregulation of bFGF and CNTF mRNAS in the rat retina. J Neurosci 15:7377-7385. Medline Wittmer CR, Claudepierre T, Reber M, Wiedemann P, Garlick JA, Kaplan D, Egles C (2011) Multifunctionalized electrospun silk fibers promote axon regeneration in central nervous system. Adv Funct Mater 21:4202. CrossRef Medline

Wolf MT, Daly KA, Reing JE, Badylak SF (2012) Biologic scaffold composed of skeletal muscle extracellular matrix. Biomaterials 33:2916-2925. CrossRef Medline

Xu Y, Patnaik S, Guo X, Li Z, Lo W, Butler R, Claude A, Liu Z, Zhang G, Liao J, Anderson PM, Guan J (2014) Cardiac differentiation of cardiosphere-derived cells in scaffolds mimicking morphology of the cardiac extracellular matrix. Acta Biomater 10:3449-3462. CrossRef Medline

Xue H, Zhang XY, Liu JM, Song Y, Li YF, Chen D (2013) Development of a chemically extracted acellular muscle scaffold seeded with amniotic epithelial cells to promote spinal cord repair. J Biomed Mater Res A 101:145-156. CrossRef Medline

Yang L, Long Q, Liu J, Tang H, Li Y, Bao F, Qin D, Pei D, Liu X (2015) Mitochondrial fusion provides an "initial metabolic complementation" controlled by mtDNA. Cell Mol Life Sci 72:2585-2598.

Yin Y, Cui Q, Li Y, Irwin N, Fischer D, Harvey AR, Benowitz LI (2003) Macrophage-derived factors stimulate optic nerve regeneration. $J$ Neurosci 23:2284-2293. Medline

Yoon H, Kim G (2010) Micro/nanofibrous scaffolds electrospun from PCL and small intestinal submucosa. J Biomater Sci Polym Ed 21:553-562. CrossRef Medline

Yoshida K, Muraki Y, Ohki K, Harada T, Ohashi T, Matsuda H, Imaki $J(1995)$ C-fos gene expression in rat retinal cells after focal retinal injury. Invest Ophthalmol Vis Sci 36:251-254. Medline

Yrjänheikki J, Keinänen R, Pellikka M, Hökfelt T, Koistinaho J (1998) Tetracyclines inhibit microglial activation and are neuroprotective in global brain ischemia. Proc Natl Acad Sci U S A 95:1576915774. Medline

Yuan L, Neufeld AH (2001) Activated microglia in the human glaucomatous optic nerve head. J Neurosci Res 64:523-532. Medline

Zeng HY, Green WR, Tso MO (2008) Microglial activation in human diabetic retinopathy. Arch Ophthalmol 126:227-232. CrossRef Medline

Zhang L, Zhang F, Weng Z, Brown BN, Yan H, Ma XM, Vosler PS, Badylak SF, Dixon CE, Cui XT, Chen J (2013) Effect of an inductive hydrogel composed of urinary bladder matrix upon functional recovery following traumatic brain injury. Tissue Eng Part A 19: 1909-1918. CrossRef

Zhang XY, Xue H, Liu JM, Chen D (2012) Chemically extracted acellular muscle: a new potential scaffold for spinal cord injury repair. J Biomed Mater Res A 100:578-587. CrossRef Medline 